\title{
Re/turning to soil: becoming one-bodied with the Earth
}

\author{
Charles Scott $^{1} \cdot$ Tanya Behrisch $^{1} \cdot$ Monica Bhattacharjee ${ }^{1} \cdot$ Starleigh Grass $^{1}$. \\ Heesoon Bai ${ }^{1}$
}

Received: 22 December 2020 / Accepted: 15 January 2021 / Published online: 29 July 2021

(C) The Author(s), under exclusive licence to Springer Nature B.V. 2021

\begin{abstract}
This paper curates four experiential narratives and poetry by the five co-authors that illustrate epistemic and ontic shift from the Modern Western (ModWest) mindset to a holistic, embodied and animistic mindset. Coming from different cultural backgrounds, yet having been systemically influenced by the dominant ModWest views and values, each author has initiated an ongoing shift in consciousness, demonstrating how such transformations are possible. Affirming that a shift in consciousness is not simply a matter of cognitive change but is a thoroughly holistic process, the authors write in autobiographical narratives and poetry to capture and convey embodied and emplaced, experiential understanding and feelings, or 'felt sense.' Deep changes in the consciousness, such as these epistemic shifts, take the whole ensemble of "body + mind + heart + soul + spirit + the world" as the unit of change for learning. Through these writings, they sensuously and feelingly, existentiallyand-spiritually and discursively explore possibilities of becoming one-bodied with the animate Earth. They call this the re-bonding project through which they address humanity's first-order bonding rupture between Humans and the Earth community.
\end{abstract}

Keywords Modern western worldview $\cdot$ ModWest $\cdot$ Holism $\cdot$ Embodiment · Autobiographical narratives $\cdot$ Animism

\section{Abstract--Hindi}

यह शोध अध्ययन पाँच सह-लेखको के चार अनुभतवमक कहानायाँ एवं कवतिओं के चुनदि संग्रहण को पेश करती है जो आधुनकि पाश्चात्य मानसकिता से हटकर एक पूरणतवादी, सन्नहिति, और आध्यात्मकि सोच अपनाती है। सभी लेखक वविधि सांस्कृतक पृष्ठभूर्मा से होते हुएँ भी प्रमुख पाश्चात्य वच्चिरों से प्रभावति है। यह कहानायाँ है उनकी जारी उपक्रमों के जो दखिलाते है की वास्तवंकि परवित्तन सम्भव है। लेखक दृढ़ता के साथ कहना चाहते है का यह अंदरनी चेतना में बदलाव केवल एक ज्जान-सम्बंधी प्रक्रया नहीं है बल्का एक परण समगर परविर्तन है जसि लेखको ने आत्मकथात्मक, अनुभव-सम्बंधी कथाओं के प्रणाली सै पेश करि है। गहरे जागरुकता के लएि एक सम्पूरण संयोजन की ज़रूरत है जसि वद्यि में तन, मन, हृद्य,

This manuscript is part of the special issue Contemplative Inquiry, Wellbeing and Science Education, guest edited by Kenneth Tobin.

Charles Scott

charless@sfu.ca

1 Simon Fraser University, 8888 University Dr, Burnaby, BC V5A 1S6, Canada 
आत्मा, भावना, और संसार का मश्रिण होता है। अपने लेख के माधयम से यह लेखक अनुभत्तजनक, भावमय, आध्यातमकि एवं अस्ततिववान चर्चा करने का प्रयास करते है ताकी वह इस सजीव पृथवी के संग नतिांत रप से एक हो जाए। वह इस परयोजना को re-bonding अरथात नवीकृत मोलिन की पहचान देते है जसिके माध्यम से वे मानवता और धरती की सम्बंध-वच्छिछेद को सम्बोधति करना चाहेंगे।

\section{Preamble}

The mainstream North American culture is by and large behaving as though we humans are either at war against the planet earth or indifferent to 'it.' Here, as our reader can see, the usual practice is to refer to the earth by the pronoun 'it,' revealing a common attitude and perception: that the Earth is an object, mostly an inanimate one. But why should we take this alienated way of seeing, thinking about and feeling towards the planet? Treating 'it' like an inanimate thing, when 'she,' like Mother, holds us, nourishes us and keeps us alive? And some traditional cultures and individuals do see the Earth that way. Consider the work of Sam Gill (1991) on the evolution of the 'Mother Earth' figure among Native Americans, Elizabeth Kempf's (1993) collection of essays on the reference to 'laws of Mother Earth' by Indigenous peoples to call for protected areas, Joanna Hubbs' (2017) research on the worship of 'Mother Earth' in Russian culture; and Nadia Majid (2010) regarding the conceptualizing of Earth as 'Mother by the Maori.' Different ways of seeing and construing the world do exist, as cross-cultural studies reveal a whole variety, some of which may be more life-giving and life-sustaining than the contemporary North American culture saturated with consumerism, capitalism, industrialism and militarism. These "isms,"or ideological commitments are part and parcel of the human history that is known by its periodization descriptor, Modern Western (henceforth ModWest, in short). To note, "ModWest" as a worldview, mindset and attitude is not confined to the geographical boundaries of the historical West in today's globalized world. The ModWest has spread, under colonialism, throughout the world and the so-called developed and developing countries all over the planet that came to be committed to consumerism, capitalism, industrialism and militarism are saturated with the ModWest.

The ethical significance of how we come to see the world is absolutely enormous: it can be and it is now, a matter of life and death. Gerardo Ceballos et al. (2015) and William Ripple et al. (2017) stand as classic, highly-cited warnings from the Earth sciences community. The realization of ethical consequences of worldviews and values we hold is growing, although not fast enough against the speed of destruction, as the global scale of climate crisis increases and attendant human suffering deepens by the hour. One would have to be blind not to see, but such blinding is also a consequence of certain epistemic constructs we have. Our constructs are the particular lenses through which we perceive, feel and think about the world. The objectification lens that we have inherited from our modernist technoscientific-capitalistic-industrial-consumeristic period in history has blinded us so that we don't see the Earth as a living, breathing being whose ecosystems are being significantly destabilized as a result of damaging human presence and thus losing their equilibria. From this Gaian perspective (James Lovelock 2000), the Earth suffers from harm and her suffering and attempts to heal and regain self-regulation or equilibrium are manifest in largescale storms and tornados, floods and forest fires, melting ice caps, drying up aquafers, soil erosion and so on. 
The lens of objectification comes out of a particular set of worldviews that are currently globally dominating the world. Whether we use terms, such as 'ModWest' (Modern Western), 'colonialism,' 'Neoliberalism,' 'late capitalism,' they all refer to different but interrelated aspects of the same phenomenon wherein we humans do not perceive, feel and think about the world as a living being, worthy of our deepest respect or reverence, of care and of communion. The world, seen through the objectifying set of lenses, is a mere collection of objects. In his analysis of the dominant views of the Modern West (ModWest), the late ecotheologian Thomas Berry (2006) believes that we see the earth as a "collection of objects," not "a communion of subjects" (p. 149). At best, we of the ModWest mindset or worldview may pleasure ourselves with the things of Nature, which is ultimately instrumentalist; at worst, we consume, exploit, trash and destroy them as we please and desire. Such is the predominant attitude and relationship that the ModWest human inhabitants of this planet hold towards 'whatever' is 'out there.' Things and objects are simply at our disposal, and we humans of the ModWest mindset can do whatever we want to them for profit, benefit and pleasure. But what 'profit'? What benefit? And what pleasure? When humankind, along with all our Earth relations on this planet, end up losing our only Home, what profit, benefit and pleasure is there? What possible justifications could there be for this destructive attitude, relationship and treatment that we wreak upon the planet?

Whatever justification we who are still committed to the ModWest may come up with for our destructive form of life, it is also part and parcel of the objectifying worldview, comprised of the belief that humans are the superior beings on this planet (e.g., we can spilt atoms, slice genes, surgically implant an artificial heart, send astronauts into outer space, etc.), uniquely alone as a species (e.g., we are at the top of hierarchy, unchallenged by any other creatures), having the 'right' to rule over the planet and being 'entitled' to possess, make use of and even destroy, any objects or 'things,' including other beings. Whether these rights and entitlements are 'divinely' given and mandated, or self-prescribed and appointed, the end results are basically the same: the destruction of the planet. And this process has been accelerating via rapid developments in science and technology. In the end, what good is advanced science and technology when these are used to destroy the world?

There are overwhelmingly complex details to the above picture, which we are not providing here. Our point is that all the rationale and stories that are used to 'justify' our destruction of the planet come from a certain kind of worldview and attendant consciousness that sees the earth and all her inhabitants as objects at our disposal. However, let us remind ourselves that worldviews are just that: views, however persistent they may be. As such, they are contingent, not necessary. Therefore, they can be changed-however difficult such changes may be. And, at this point in human history, we must change our world-viewing lens if we want the biosphere that we call the earth to survive, not just barely, but with possibilities of sustainable flourishing.

Yet, changing one's world-viewing is not like taking off one pair of glasses and putting on a new pair. A lot more is involved: Unless and until humans perceive, feel, that is, experience Nature as one-bodied with us, precious and worthy of our reverence and devoted care, that we are Nature and that destruction of Nature is self-destruction for humans as well, we will continue on the path of ecocide and humanity's suicide, as Ronald Wright (2004) clearly illustrates in his influential Massey Lectures. Here, we emphasize the role of human perception and affection in the way we regard and treat other beings; for we need to have an immediate and visceral sense of our attachment and care with respect to the Earth. Thinking unaccompanied by feelings and sensations do not have the same transformative impact on the person as when 
all three-perception, thinking and feeling-work together. Moreover, while reasoning and justification have an important role to play, it turns out that they really serve emotionality, perception and values, as the work of social psychologist Jonathan Haidt (2012) shows with respect to values and perceptions and the work of neuroscientist Iain McGilchrist (2012), in relation to emotions and perception. As such, to educate ourselves, that is, to learn to become one-bodied with the earth, we need to re-educate the citizens' emotions and perceptions to be aligned with respect, reverence, care and empathy with the earth. This is the major educational challenge we face today, as multiple global-scale crises loom, including the COVID-19 pandemic that is currently putting us through a second wave of infections.

To reiterate, we need to see and experience the earth as our own body and develop intimate and sacred relationships with her. As philosopher and theologian Raimundo Panikkar (1990) compellingly puts it, "[n]o ecological renewal of the world will ever succeed until and unless we consider the Earth as our own Body and the body as our own Self" (p. 244). As long as we continue to see the world "out there" as separate from us and consisting of 'things' and 'objects' that we can use however we please, we will not cease from exploiting them and discarding the earth-beings. Even when we like them, love them and want to protect them, that will be out of possessive love, motivated by our wants, not out of respect for the other, valuing the other intrinsically, for their sake, not just for our sake (Bai 2001, 2003). Possessive love does not recognize and honor the sanctity of the beloved.

What does it take for us to learn to intrinsically value the other/more-than-human beings? How do we need to see them and what feelings and attitude do we need to have for us to experience them as intrinsic beings, exciting in their own right and existing for themselves? And how do we come to see them and relate to them as such? How would these changes affect the way we do science? The questions asked here are educational as well as epistemic in nature: 'Coming to see' is part of the process of coming to know, which involves rearrangement of a complex set of embodied and embedded sociocultural influences and conditioning called learning.

We call for an epistemic shift away from the currently dominant way of seeing human beings as deserving to be prioritized over and above other beings, exercising death-dealing power over them and harming them with impunity. The epistemic shift will bring an ontic shift in the way that we come to see, feel, relate to and differently embody an alternate sense of reality.

In this polyphonic paper, we curate four experiential narratives and poetry by the co-authors, each in their different voices that illustrate abovementioned epistemic shifts. Coming from different cultural backgrounds, nonetheless having been systemically influenced by the dominant modernist worldviews and values, the authors each managed to initiate an ongoing shift, demonstrating how such transformations are possible. Because we suggest that shifts in consciousness are not simply a matter of cognitive change in the 'rational circuitry in the brain,' as it were, such as deployment of reasoning, rhetoric, calculation and behavioral prescriptions, we write in autobiographical narratives and poetry to capture and convey embodied and emplaced, experiential understanding and feelings, or 'felt sense.' The latter is a central psychotherapeutic concept elaborted by the philosopher Eugene T. Gendlin (1978) who developed a therapeutic modality named, 'focusing.' Deep changes in the consciousness, such as these epistemic shifts, take the whole ensemble of "body + mind + heart + soul + spirit + the world" as the unit of change for learning. Through these writings, we will sensuously and feelingly, existentially-and-spiritually and discursively explore possibilities 
of becoming one-bodied with the animate Earth. We call this the re-bonding project through which we address first-order bonding rupture, namely, between Humans and the Earth community.

\section{Narratives}

\section{Campania fastness, a mighty intelligence (Tanya Behrisch)}

As a living being, Campania Island exerted a magnetic tow on my body before I connected with the island directly in July 2020. I cannot discern a gender with Campania, so speak of Campania as 'the island' rather than call Campania 'it,' 'she,' 'him,' or 'they.' Like all places and beings, Campania is singular. I first dreamt of visiting the island while skimming John Kimantas' (2011) kayak guide to B.C.'s north and central coast (p. 223). Kimantas' single image of barren mountains looming above a creamy white beach and viridian water started working on my imagination four years ago. The island's draw on me amplified during a paddling trip in 2019 while wandering naked along a shell beach $35 \mathrm{~km}$ south of Bella Bella and Superstition Point where I met two elderly boaters, Loyd and Sandi, who were exploring the bay where we were camped. After grabbing clothes, I learned they had spent 40 years exploring Xai/Xais territory in British Columbia's Inside Passage (Kitasoo / Xai'xais Nation, n.d.) near the settlement of Klemtu on Swindle Island. They'd seen eight Spirit Bears and other wild kin such as grizzly bears, humpback whales and wolves. Invited for a glass of wine aboard their boat later that day, Loyd unfurled his marine chart and pointed to Caamaño Sound where Campania Fig. 1 resides with Aristazable, Princess Royal and the Estevan islands. To reach Campania by kayak would require three weeks and several significant crossings of exposed water, each three hours of paddling and potentially exposed to 20-30+ knot winds flowing down the coast. My imagination fastened upon this land and its visceral pull stirred within me. In the midst of worries such as my father's cancer and COVID19, I joined my husband and two kids, ages 14 and 16, on a three-week kayak trip to Campania in Summer 2020. The Kitasoo/Xai' Xais band granted

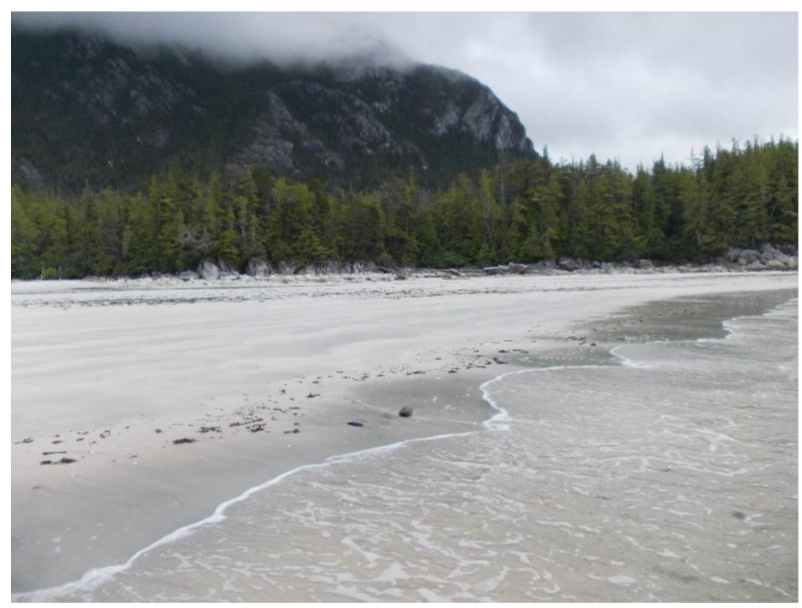

Fig. 1 Campania fastness, a mighty intelligence 
us permission to paddle through their territory, requesting we avoid their communities to minimize the spread of COVID19. Social isolation fit with our plans.

From a distance, Campania appears blue, hazy, bulky and mountainous. We left Princess Royale Island at 6 a.m. on day seven of our 20-day trip, traveling through Caamaño, Campania and Estevan Sounds. Our early start was intended to minimize exposure to increasing winds which raise the danger of capsizing. Ocean swell rolled in from the Pacific and crashed on Campania's southern rocky coastline. Landing a brittle fiberglass kayak was impossible. We paddled north a kilometer offshore to avoid shallow underwater reefs, which amplify swell and induce nausea and fear in paddlers who have no protection from waves and wind.

Gazing at Campania from offshore, the island appeared as a stronghold, a fastness. Now in Campania's water, I gazed directly at the land, heard Campania's crashing coastline and smelled Campania's air. We were in contact. From a kilometer offshore, Campania smelled bracing and alive. Pacific waves smashed into Campania's body of rock and sand creating a constant wall of sound from offshore. My painter's eyes feasted on the island's rich palette of colors: sap green, Prussian blue, Payne's and Portland gray, raw sienna, burnt umber, titanium white. Campania emanated self-hood and dignity. At around noon, we landed. Disembarking on Campania's white sand was a revelation and a caution. We were strangers, not necessarily expected or welcome. The first footsteps I saw were wolves.' Hauling my gear to dry sand above the high tide line, I saw wolf scat and prints amidst beach grass and driftwood (Fig. 2).

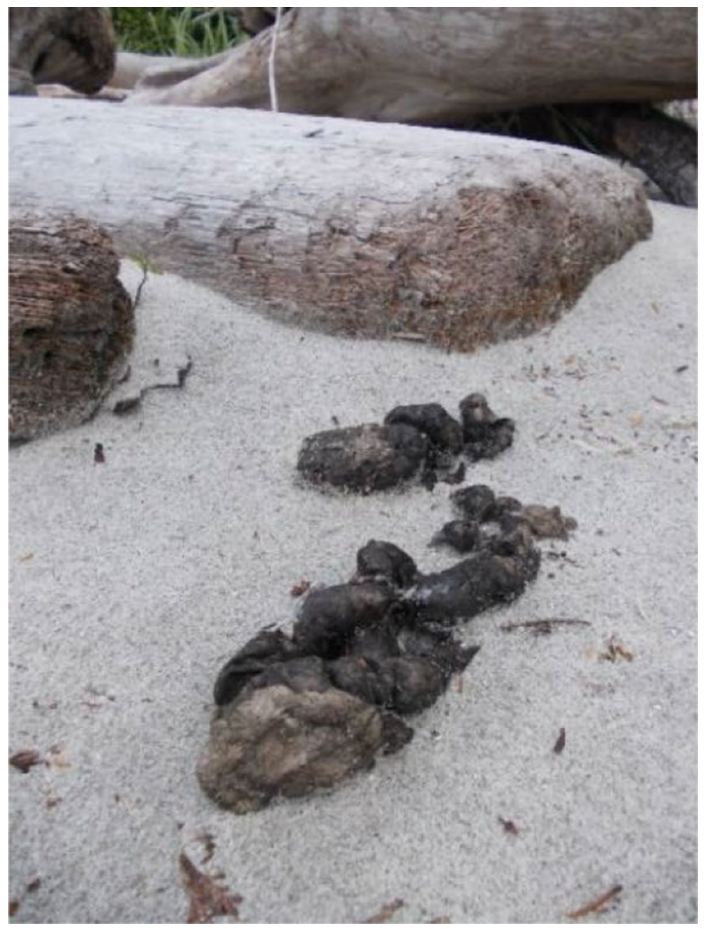

Fig. 2 Wolf scat on Campania; lots of it 


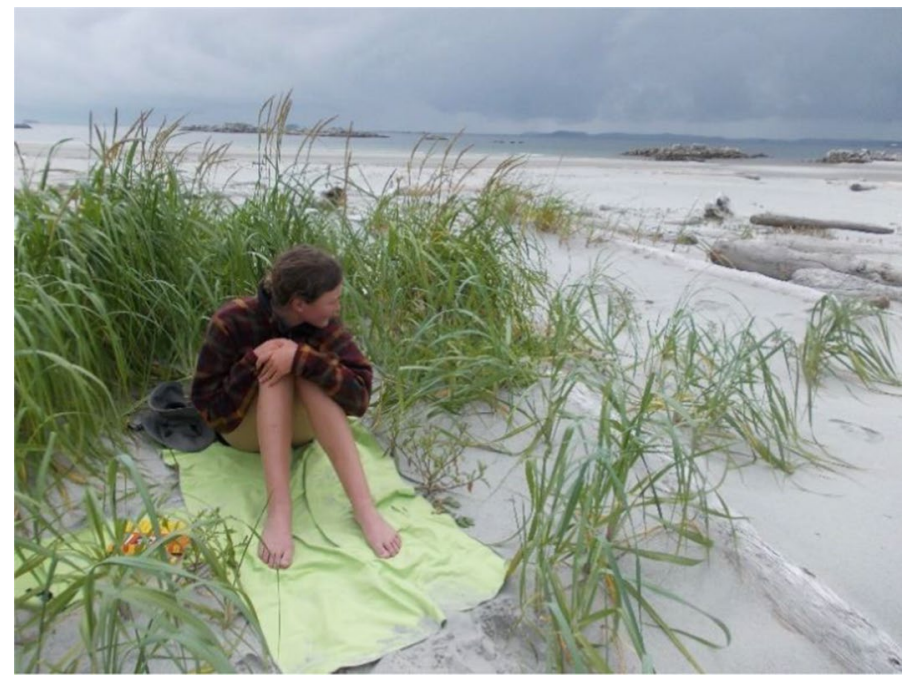

Fig. 3 Daughter and wind storm on Campania

Ravens cawed, announcing our arrival to Campania's stronghold. I sensed a mighty intelligence become alert to our arrival, as I become alert to a new person who enters a room. A hundred meters upland from the waves, the island was quiet, sentient, alive and watchful. Barren mountains loomed behind forest, the fastness seen from offshore. I was humbled to be on Campania Fig. 3 and spent $40 \mathrm{~h}$ immersing my body in the island's fresh water streams and salty waves, listening to wolves howling behind a screen of trees and sleeping on its sand.

Two wolf pups wandered onto the southern beach, a yearling and a newborn, sniffing the ground for food and stumbling into one another as puppies do. Their mother appeared, an elegant beauty, growling and admonishing them to stay close to her while strangers were on the beach. We kept our distance, awed by their relaxed playfulness in our midst. We later hiked inland, climbing granite hills beneath Campania's mountains in search of lakes. Campania regarded me as a source of food; insects feasted on me from the moment I landed. I could not refuse the island this gift of myself, my tribute to the land. Hot and salty, I smeared black flies' corpses along my clammy skin. These were instantly replaced by swarms of new eaters. Filled with my blood, they will die and join the island's humus to nourish creatures such as birds, fish, rodents and wolves. This was the most personal offering I could give to this living sentient place and I did not begrudge giving this gift. I did however take refuge from the island's relentless feasting on my body in a chilly pond beneath sheer mountains.

Descending later to the ocean, I swam to rinse my bites and was surprised to see fresh blood flowing from open sores. The insects' anticoagulant prevented my blood from clotting and I continued to feed the island with my gift of blood that streamed into the sea as I swam. Later, amidst the sighs and groans of a humpback whale in Estevan Sound, I lay down on the damp sand with my daughter and lapsed into dreaming.

Over a three-week kayak trip in July 2020, I stayed on Campania Island for two days. Sleeping, eating, fishing, resting, swimming, exploring and hearing Campania's many creatures talking to each other gave me a glimpse of the island's earthen body and saline environment. Campania's generativity flows into the ground, the air and water of Caamaño Sound. The island's generativity pulses through waves rolling inshore and back out again, 
through the diurnal cycles of light and dark, fresh water streams gushing down from the mountain fastness, creatures cycling through stages of birth, growth, death and renewal. What dies here is absorbed into Campania's living body, re-emerging back into abundance. This land senses and feels and by extension, I believe all land is sentient, whether battered and mistreated or honored and respected as our kin. Land is alive.

I became conscious of Campania's pull on me four years ago. Each intervening year that I paddled for periods of 3 weeks south of the island I was in Campania's orbital pull and the island pulled on my imagination. Returning to Vancouver after each three-week kayak trip, the island talked to me in a register impossible to ignore or dismiss. Visiting Campania, immersing myself in the island's fresh water and ocean, dreaming on sand, riding offshore swells in my kayak, hearing wolves' howling, the island's life force pulsed around, through and in me.

I felt a strange familiarity with Campania, born from thinking, dreaming and imagining the land for four years and paddling south of the island for four consecutive summers, always aware of the island looming north of us, breathing, dreaming, living a private life. To finally be with Campania, to stand on Campania's surface, was to arrive in a somewhat familiar place. I wondered if the island sensed what I felt. I felt I was in the presence of a mighty intelligence and that my frailty and earthen composition was sensed by this magnificent land. Caked in salt, sand, smoke and grime from the previous seven days' paddling and camping, I was porous and open to Campania, unseparated from the island's saline earthen elements and its creatures.

\section{Campania Island}

White soft beach alive, awake

Mamma wolf and two pups

Feed on soft bodies

Washed up with the tide

Recline on my towel

Soak up the mystery

Of Campania my kin

Two motor boats arrive

Families and picnics appear

Where wolves were just scavenging

Less than one minute ago

Campania inhales

Holding breath tight within

Cheerful laughter shatters the silence

Anchor chain rumbles down

Oxygen vanishes, stillness is gone

Friendly but hated

I lie down

To wait newcomers out

Hours later, I'm dreaming

Anchor chain drills the air

Two motors roar

Shrieking cheerily "we were there!" 
I sink back into dreaming

Whale sighs in Estevan Sound

Retreating motor beats down

Other quiet north of here

Sun on my cheek, Campania exhales

Incoming tide

We're together again

I became aware of Campania's sentience as I do of person who quietly enters a room; the peripheral awareness of each other, the nod of mutual recognition. After dumping my gear, I grabbed my camera to walk along the white sand beach, stepping over piles of wolf scat embedded with crab shells and small animals' bones and noting circular grooves made in the sand by beach grass blowing in the wind. Animal prints, both fresh and eroded, covered the upper beach, revealing multiple stories and lives being lived in this remote fastness. I climbed down into a stream bed and knelt to peer at rose-colored clam shells piled in drifts, discarded by animals passing on and returning to the mineral world. I took photos of granite boulders perched precariously amidst scrubby cedars lashed by wind. The south end of the beach felt remote, silent, watchful and ominous and I soon retreated back to where my family was setting up our tent. Shortly thereafter, three wolves appeared where I'd knelt in the stream bed. I understood the feeling I'd had of being in another's territory. This place was home to others, creatures who knew Campania intimately, more than I could know the land in two days. I felt the island's nod of recognition towards me as a fellow creature but remained wary. Campania was not my home and nor was I Campania's daughter. I felt a kinship in the way two creatures regard one another's presence.

Writing back in the city, it's habit to imagine Campania "out there" in the wilderness. But what is wilderness? Is it out there? What if this reference to "out there" is just a habit and not grounded in what embodies true wilderness? Gary Snyder (2010) writes,

wilderness is a place where the wild potential is fully expressed, a diversity of [...] beings flourishing according to their own [...] order. [...] To speak of wilderness is to speak of wholes. Human beings came out of that wholeness and to consider the possibility of reactivating membership in the Assembly of All Beings is in no way regressive (p. 12).

When I consider Snyder's concept of wilderness as wholeness and diversity, I know this is what I feel rising up through the oak floorboards of my dining room, flowing through my body and out through my nose and mouth. This awareness, this pull on my body that prevents me from floating off my chair. This is the living, sentient, peerless Other that's been here all along, pulsing, generative and intelligent (Blenkinsop et al. 2010, Abram 2010).

\section{Exploring the one in all and all in one through childhood 'meetings' with critters (Monica Bhattacharjee)}

Mid-July, 1988, Kalimpong, India.

It is a warm evening in the hilly town of Kalimpong (in the Eastern Himalayas about $50 \mathrm{~km}$ east of Darjeeling), famous for its aromatic tea, growing all over its chabagans (tea-estates) and for being a summer retreat of the erstwhile East India Company, a sixteenth century British trading company that managed to seize and colonize large parts of 
South- and South East Asia. I am in my grandparents' house and it's what we call the monsoon season in India. The rains are furious and torrential. And accompanying this torrent is a furious flurry of insects, some of which grow strange wings in this wet season but most of which are generally harmless. I am 8-years-old and having lived in the capital city of Delhi, I shriek and shrivel at the sight of these flying "pests". Here are some snippets of a (translated) conversation I recall having with my grandpa one evening.

Grandpa: (seeing me jump and skip to dodge little bugs) Why, you seem very unsettled?

Me: These bugs! How do you live with these?

Grandpa (laughs): It is their home too. And home is nowhere and everywhere.

Me: (My 8-year old brain bewildered): What??

Grandpa: Seems like you forgot that when you were little, you would be fascinated by them. You even played with some! What's wrong now? It seems the city changed you, little one.

Me: (Confused) ... yeah cos they are all over your home... and you say this is their home $\quad$... and (catastrophizing) they might "kill" us!

Grandpa (cracking up with laughter): Oh my, you have grown up a lot (sarcasm detected in hindsight). Yes, it is their home as much as it is ours. They were here on this planet way before we even stepped foot. Some are harmful, but many aren't. They do more for you than you for them. Your karma is not just to yourself and to your kind, it extends to every animal and plant alike, every six-legged creature too. Observe your own reactions ... just observe ... and let that attention awaken your mind.

The last sentence did not really do much to my eight-year old mind then, but for some strange reason, it has vividly latched on to my memory. This prompting to 'awaken' is what I understood later on to be an extension of the notion of Boddhicitta which is the enlightened mind borne out of compassion that is initiated when self-reflexive awareness helps reroute the conditioned mind from the path of reactivity to attention. My grandpa passed away long before I could clarify concepts like Boddhicitta with him. However, to put his advice into context, his words fall along the lines of an ecospiritual pathway informed by an understanding of pratitya samutpada (dependent origination) and the relationality of all BEINGS in nature. Despite a typically common fear of or scorn for bugs and critters, they are vital to our ecosystem, with National Geographic calling them the 'lever-pullers' of the world and in true neoliberalist spirit, attributing them with contributing $\$ 75$ billion to the U.S. economy via pollination, some providing food for animals, controlling pests and clearing up decomposing plants and animals.

Late October, 1990, New Delhi.

Two years later, back at home. It is the season of Deepawali, the Hindu festival of lights. And the lights are equally attractive to humans and bugs alike. These bugs are referred to as "Kali poka" and are drawn to light sources. They are harmless to humans, although in some instances, they are known to infect paddy fields. They are seasonal and an exception in the otherwise arid climes of Delhi. Most live for less than a day, attaining maximum activity in the vicinity of artificial sources of light and dying out the same night as the lights go out. Here is a brief translated excerpt from my conversation with some neighbors.

Neighbor 1: Yikes! These bugs... Diwali pey maze kare ya makkhi maare! (Should we spend the festive season celebrating or chasing bugs?).

Me: (Having grown up somewhat after the summer exchange with my grandpa two years ago and not too perturbed by the fewer number of critters in comparison to that episode): It's not too bad, Uncle. They're just thronging around the light. They don't really sting or bite. 
Neighbor 1 (Staring at me in disbelief): Beta (Hindi word of endearment used for a child), what's up with you? These are dangerous!

Me: How?

Neighbor 1: Well, okay ... not dangerous. But annoying for sure ...

Neighbor 2: I'll call the pest control guys today. This is a nuisance.

Me: But uncle, they don't live beyond the night. What do you want to call pest control for?

Neighbor 2: To prevent these from entering our spaces in the first place.

Me: Uncle, my grandpa said that we can learn to live with them ...

Neighbor 2 (Expression turns from exasperation to amusement. Laughs incredulously): This is your house, Beta. Not theirs. And old people sometimes cannot think straight.

Looking back on these childhood memories, I see many polarities on many different levels, human-non-human, insider-outsider, urban-rural, acceptance-resistance, dual-nondual, inclusive-exclusive, possession-dispossession and most lucidly, the objectified otherness of the bugs, which in our objectified consciousness does not allow us to know by participation but by abstraction and conceptualization (Bai, Scott et al. 2009). By acknowledging the significance of shared space with our critter community, my grandpa taught me a vital lesson early onthat our motivations and intentions shape our perceptions and allow us to experience the world the way we do. Through my years of growing up, frequent moves and changes in location and my own situatedness as an immigrant first in Singapore and then in Canada, I have often witnessed profound inner conflict as I struggled to reconcile my deep seated spiritual quest to realize the unified consciousness that binds us all with the pragmatic vantage points of living the first-world life, of staying on-task, setting and meeting specific goals, and most noticeably, of drawing and defining boundaries shaped by the dominant narratives of growth and advancement in the homo economicus worldview. The "enlightenment mentality" that Weiming Tu (1996) believes to be the "most dynamic and transformative ideology in human history" which to most people represents all things modern and progressive needs to however be understood in greater entirety, specifically through the historical context of western expansion, colonization, imperial subjugation, and their connections to the current world order. Speaking from an alternative standpoint/ Confucian perspective, Tu lets out a cautionary tale about the dark underside of the "unbound Prometheus" of this unchecked growth, development, exploitation, use and abuse of resources - natural, environmental and human-in the capitalist narrative of 'advancing' civilizations dictated by the market value of all things.

The more recent concepts of Buddhist ecodharma (Loy 2019) aiming to counter our widespread ecological crisis brought forth by industrial greed and indiscretion around unchecked production and consumption is not merely about climate change and global warming but on a much larger scale, a social and spiritual crisis that cannot be fixed by just switching to alternative energy resources. It requires a radical restructuring of our ways of being in this world and one of the ways to enable such conditions rests in Jiddu Krishnamurti's advice on consciously moving from an organized to an organic society (De Sousa 2012), which works on an attunement principle where the needs of the individual and society are the same and the integral connection and one-ness in living is recognized and prioritized. This is easier said than done in a world within a dominant worldview of philosophical materialism driven by the need to constantly strengthen and maintain the sense of the separate I-entity in hedonic, desire-driven conditions and instrumental motivations. Critics may opine that a stable I-entity is a necessary pre-requisite for other-related ethics but the inherent problem and solution here lies in how we identify with that I-entity. Are we identifying ourselves with our projected persona and moment-to-moment sensations, perceptions, emotions and desires within our limited material apparatus or are we identifying ourselves with a deeper awareness of the formless, 
undivided self that is not limited to the body and mind it is only partially contained within, but is one with our fellow-human and more-than-human entities, with the earth and sky and all living, breathing beings in between? That is my key question in our re-bonding project with an intention to not elicit an answer per se but a deeper self-inquiry and exploration of our inner landscape.

\section{A blade of grass (Starleigh Grass)}

I am a Tsilhqot'in educator who has done most of my formal education in Okanagan territory. I taught in public secondary schools in the traditional territories of the Nlaka'pamux and St'at'imc people. When I moved to North Vancouver, I was already well grounded in Indigenous theory. Scholars such as Leanne Betasamosake Simpson, Margaret Kovach, Shawn Wilson, James Youngblood Henderson, Jeannette Armstrong, Sandy Grande, Bill (William) Cohen, Marie Battiste informed my graduate research (Grass 2014). I felt grounded in my communities of origin and my teaching communities. When I moved to the lower-mainland I was challenged to put into daily practice the teachings that I had obtained from community and Indigenous scholars. When I did acknowledgement of territory, I felt disconnected and hollow. Even with a strong cognitive foundation, I was disoriented in my new home.

However, a moment shared with my niece on my own territory shifted my perspective and helped me to better understand and practice meaningful acknowledgement of territory. The embodied experience of being on the land with family helped me make meaning of my home away from my traditional territory. This experience also helped me find a way to practice integrity as an Indigenous person living in someone else's territory. I offer this moment in a poem in hopes that it will enrich the reader's own ability to meaningfully acknowledge territory. I dedicate this poem to Indigenous scholars trying to find their intellectual, emotional and spiritual footing while working and studying away from their traditional territories.

\section{Acknowledgement of territory}

Family fishing camp on the banks of the Chilco River,

Last day,

Jay and Candice are packing the truck,

I follow Mel while she runs around.

Clouds of fine dust rise after every step,

Grass as high as her head,

So much motion,

Exuberant joy.

She stops,

Suddenly,

Transfixed by a blade of grass,

Slowly her little hand reaches out,

Softly holds it between forefinger and thumb, 
Eyes transfixed,

She gently moves her way up to the top,

Time stops.

I love her so much right now.

Here is my niece,

In the place where my ancestors have fished since time immemorial,

Respect, relevance, reciprocity, and responsibility means to be a trusted adult who creates safe space for this moment to happen.

I feel a fifth $\mathrm{R}$,

Reverence,

For the relationship between our people, and this land,

In perpetuity.

She explodes into action again,

Weaving back and forth along little trails through the grass,

Little trails that little children have been making all summer.

There are hugs,

Long goodbyes,

Half smoked salmon in my trunk,

I start the long drive,

Back to the city.

It was my first season living on the west coast,

I routinely cried when I drove westbound on the Port Mann,

Lonely for the culture, people and land of the interior.

During this return, I felt only guilt for crying those tears.

The responsibility I feel towards exercising Tsilhqot'in rights on the land,

The reciprocity I feel towards ancestors and future generations,

The respect that I have for what it means to survive in our unique climate,

The reverence for the beauty of place,

These are things I had not taken the time to cultivate in my new home.

No wonder I felt so lonely.

I knew the path to living a meaningful life in my new home,

Was to learn about the history of the Squamish, Musqueam, and Tsleil-Waututh nations,

Contribute to Indigenous communities,

And above all,

To love Squamish, Musqueam, and Tsleil-Waututh Territory the same way I love my own land.

To me acknowledgement of territory means celebrating cedar,

Donating to the legal battle to fight Trans Mountain,

Appreciating salmon berry,

Showing up to demonstrations,

Understanding that when the tide is low the table is set,

Understanding the impact of industrialization on that table, 
Supporting language revitalization,

Listening carefully to personal histories and community stories,

Seeking out work by Squamish, Musqueam, and Tsleil-Waututh academics,

Loving the land in its present state,

Unequivocally supporting Squamish, Musqueam and Tsleil-Waututh visions for the future of the land,

Chipping in gas money to go to cultural events,

Voting for candidates who advocate for accessible housing,

And cultivating awe.

\section{Connected (Charles Scott)}

I can so well remember the freedom of my childhood when my mother would just tell me to go out and play and just come back for supper; it was my invitation get lost in the nearby fields. There were no concerns about safety nor was I given a list of prohibited activities or locations. I would spend day after delightful day exploring the fields. Inspecting. Watching. Prospecting. Sifting. Probing. Burrowing. Delving. Reconnoitering and orienting. Touring and traversing. Turning things and myself inside out. Being still. Leaving no stone unturned, no plant untouched. I discovered and was befriended by birds, insects, mice, frogs and tadpoles, minerals and fossils, plants of every kind and leaves of grass - and in the midst of all this getting delightfully and deliciously dirty.

Those connections gave me both a sense of place and a community whose comings and goings, dancings and weavings, made sense to me.

Later, when I spent a couple of years in contemplative solitude in the east Kootenay woods of British Columbia, I once knelt down by a patch of ground in a grassy opening in the forest. Looking intently, I could see, beneath the leaves of grass, clover and other growing plants, the decaying, old grass, the leaf and twig litter and beneath this, the duff and the forming, topmost humus layer that was crumbly and dark brown in color. I could see ants, beetles nibbling - a grasshopper leapt in and then, just as quickly, was gone. I could smell that slightly sweet, earthy, forest compost smell as I bowed down to sniff. I became literally entranced by this experience, realizing that in this small patch of ground, that I would barely glance at when walking by, was an immense ecosystem whose many players were interacting in a thousand ways, nonstop. And as this realization deepened, a felt a sense of immersion in this system stole over me; I felt deeply connected to these few square centimeters.

But that wasn't the end of it. That sense of immersion now expanded up and outward, rising, spreading so that I now was connecting, not only with this small, grassy patch, but with widening, expanding spheres: the larger meadow, the forest, the air just above with its buzzing and flittering insects, human communities and settlements, larger and larger atmospheres. Whereas I first felt connected to an ecosystem that was beneath me, now I felt immersed as part of something surrounding, engulfing, incredibly vast, a rather global, even cosmic ecosystem that contained, well, everything. There were no distinctions of what belonged or did not; everything was seamlessly connected. It truly was a "spell of the sensuous" (Abram 1996).

I am certain my contemplative practices contributed to my ability to perceive these ecological webs of relationships and my connections to and immersion in them. To this day, some 45 years later, that felt sense of being part of something enormous, cosmic in 
scope, is still palpable. When Whitman (1933) writes in "Song of Myself" "I am large, I contain multitudes," I understand.

What I learned from these experiences is twofold. First, that when natural surroundings are apprehended by a child as inviting, welcoming, safe locations, there are innumerable opportunities for the child's native curiosity to be set free and for the child to feel at home in natural surroundings. Second, these profound senses of connection occur, if you will, through body, mind and spirit. Yes, contemplative practices and orientations appear to increase the possibilities of realizing a deeper, more mind-andheart-felt, intimate connection to and immersion in our surrounding environments. The knowing is very much an embodied knowing but it also involves the capacities for awareness through the sense of esthetics, the emotions, the intellect and the intuition. We can develop these various capacities for awareness and intelligence (Cavas et al. 2020; Wilber 2017, pp. 575-579).

\section{Golden soil (Heesoon Bai)}

I would like to share a story of my own healing and awakening. Light rain was sprinkling that afternoon: the day we were digging up my father's decomposed body from the grave on a mountainside cemetery outside Seoul, Korea. I traveled to Korea that fall to fulfill two missions: to give an invited talk at an academic conference and also to cremate what remained of my father's body after 40 years in the ground. There was no one left back in Korea from my family of origin: all my siblings had immigrated to North America, leaving my father's grave unattended by his family. This posed practical problems at that point in time as the cemetery by-law dictated that we would have to either vacate the grave or repurchase it for the next installment of time. My siblings and I decided that it was time to terminate the tenure of the grave and cremate my father's remains.

The workmen who were opening up of the grave were all ready to commence on their work when my husband and I arrived at the gravesite. They used manual tools only in digging down a domed mound of a grave - the traditional shape of Korean graves. The supervisor who was overseeing the crew, instructed me to come close to the edge where they were digging and ceremonially witness the operation. In fact, prior to their digging, it was my assigned duty as the child of my father to conduct a small ceremony of pouring alcoholic beverage and offering some traditionally prepared food items in honor of my father and my ancestors. After offering the food and drink and making a series of prostrationbows, I stood by the grave and watched the men open up the grave, dig down deep and after a while pick out and bring up the bones, placing them in a cardboard box next to me. After all the bones, including the cranium, were picked out from the soil, I was instructed to carry the box of bones myself, as this honor and duty belonged to me, to the waiting car that would be driven to the crematorium some distance away.

What most astonished me in this entire process were the appearance and the fragrance of the soil. It was deep, dark golden colored brown soil: what we called in Korean, Hwangtoh (literally, yellow earth). There was complete absence of any foul smell from decaying corpse but only pleasant, sweet smell of moist fertile earth. The same good earth scent wafted from the box of my father's bones that was held against my bosom when I carried it and then rested on my lap in the car.

Since my father's corpse was wrapped in yards of hemp cloth, rather than put into a coffin and was buried directly into the earth, the decomposition process must have gone 
smoothly and speedily. All the creatures of the soil went to work and worked hard on returning the bio-matter that composed the body to the soil. I was witnessing the great cycle of earthly life at work. Human animals are really creatures of the soil. It's really soil that is responsible for sustaining creaturely lives on this planet. No soil, no humans, no society.

With water and sunlight added to soil, the phenomenal world of life in all its glory and gory is born and sustained, until creatures have to die and their bodies received back into the soil. Hallelujah to its power of transformation and regeneration!

Was there also a sense that the soil absorbed the soul, too? Looking at the golden soil and smelling the good earth scent, I couldn't help feeling a sense of release and even cleansing of the 'soul' that, in my father's case, was very tormented in the course of his life's tragic and traumatic events: early abandonment, Japanese colonialism, Korean War, unending survival struggles. All the suffering that my father endured in his very difficult life and the wounds that his suffering inflicted on himself and on others close to him, looked as if completely cleansed by the Great Decomposition.

My father returned to the soil, made this rich golden humus that I was touching and smelling. All once-lived bodies return to soil and become humus. Soil is the body.

Witnessing, with astonished and humbling awe and gratitude, the fragrant deep golden soil side by side with the bones of my late father was a moment of deep awakening for me. I no longer feared death. I fully accepted the great cycle of creaturely life and death. I felt my existence as being an integral part of this earthly drama of coming from the soil and returning to soil. My earthly being and soil are one. Such is another lesson that my father imparted, even in death, from the depths of the soil.

\section{Post-amble}

Speaking from within the North American context, although we have reasons to believe that what we have to say applies to the whole world, the global consumerist culture stands solidly upon instrumentalist values that treat the earth as an object to be exploited for notions of human progress. Historically speaking, for instance, early settlers arriving from post-Reformation Europe on the North American east coast were heavily influenced by Protestantism and the drive towards technical advancement. While religious scholars such as Peter Harrison (1999) have argued that Genesis did not advocate for a 'domination' over or 'subduing' of nature, Harrison, among others, goes on to argue that the texts from Genesis were interpreted by religious followers in ways that justified environmental degradation. In writing about how the teachings of Genesis were applied from the seventeenth century onward, Harrison states "There are numerous examples that serve to show how this new impulse of dominion was incorporated into the rhetoric of scientific progress in the seventeenth century" (p. 98). He goes on to cite the words of Francis Bacon and his thesis of dominion, which was then adopted by the Royal Society.

These influences comingled to forge a colonial attitude which reduced land and indigenous people to objects to acquire, 'savages' to subjugate and gain mastery over, all justified by a supposedly superior 'scientific' intelligence. George Grant (1969) describes settlers' first encounters with the continent's "almost indomitable" land 400 years ago, 'the primal' (p. 13). This primal encounter four centuries later endures, perpetuating in the instrumentalist drive for mastery over the earth today. The ethos of domination and control has spread, from England, the epicenter of modernization and industrialization, to all 
corners of the globe in the last few centuries. As a global phenomenon, left behind are blood-stained and tear-saturated fields of sentient suffering and an increasingly polluted and eroded planet whose vitality is waning.

The current humanity is indeed facing a crisis, as the Earth scientists cited in our preamble have noted: a critical turning point at which we can continue to walk down the path of destruction to demise or we can turn around to undo the harm we have been perpetrating and repair the damage. We have outlined in this paper, albeit in quick sketches, the instrumentalist mindset based in an objectifying worldview as a source of problems and suggested a shift of ontic and epistemic paradigm away from control, mastery and domination towards one that recognizes participation of the earth and the more-than-human world and their active and shared agency in co-creating and evolving Earth community.

Thus, we have Tanya's intimate connection to place through many lines of cognition; she notes her "imagination fastened upon this land; I felt its visceral pull stir within me." She notes a fusion, adding she is "one-bodied with Campania and all land, what I feel is an extension of what Campania feels, what all land feels." She is knowing through what she refers to as "being-one-bodied mode." Monica writes of how a self-reflexive awareness fosters the compassion that leads to enlightenment; it is an attentive consciousness that makes this movement possible. That attentive consciousness, and not any purely rational thought process, reveals relationality among all beings. It is a consciousness developed through an embodied participation with others.

Starleigh shares the embodied experience of her niece being 'transfixed' by the encounter with a blade of grass, an encounter made possible first by close viewing and then when she "Softly holds it between forefinger and thumb" and time stops. Charles points to the sensuous encounter with a small patch of meadow and its many inhabitants. He acknowledges this as a holistic form of knowing that includes "body, mind and spirit," as a way of knowing that integrates several epistemologies and transcends a solely intellectual awareness. And Heesoon writes of her fully accepting the great cycle of creaturely life and death in witnessing her late father's body having been reintegrated into the soil. She affirms that her "earthly being and soil are one."

Our paper here thus joins others' efforts in recent years to shift the dominant epistemology and ontology. For example, adopting a posthumanist perspective, Jeong, Sherman and Tippins (this issue), offer an "alternative onto-epistemological stance," a transformation grounded in what they refer to as the "intra-active nature of the world" and the deep awareness of not only ecological situatedness but also ecological being, a profoundly "relational ontology." They envision a new scientific literacy that "... will enable us to re-vision our understanding of ourselves, coming to know we are woven as part of something bigger ...", as part of "the entangled processes of planetary ecology," as "interwoven" beings.

And when Roth (this issue) posits a relational ontology that is dynamically grounded in "flux and becoming," we can relate! Although the essay here is focused on learning and development in the contexts of science education, the fundamentals still apply to our work. In Roth's vision, material things are seen as animated, alive; process predominates. "Instead, in an eventual ontology grounded in the primacy of flux, where the whole world and all of its parts are events, the focus is on joint becoming of events that are already related." Later in the same essay, Roth re-emphasizes that "there is no stable subject but a line of becoming"; there is "continued becoming" among beings who are not merely subjects or objects.

Such views have been part of the world's many wisdom traditions, including the contemporary Indigenous works, as we alluded earlier in this paper. Emerging theories of agential realism (Barad 2007), affect theory (Massumi 2015, Hardt 2015) and philosophical 
animism (Plumwood 2002) all echo uncannily the central precept found in the writings by Indigenous thinkers. Many indigenous world views hold that all things are spirit and are gifts from the creator (Hill 2008, Kimmerer 2013). In a similar way, world wisdom traditions (Buddhism, Hinduism, Jainism, Daoism, Sufism and so on) also uphold the sacredness of the earth while offering practices of reverence and compassion. While diverse in origin, these ontologies share the notion that all beings are connected and have the power to affect and be affected. This understanding underlies the foundational concept of, for example, the karmic continuum (Yung-Jong Shiah 2016; Sharma 1990; Rankin 2009) that serves as a cornerstone in the Eastern practices, such as Buddhism, Hinduism and Jainism.

The karmic continuum concept relates to the co-arising of events, simple or complex and the links that sustain this chain of mutual causality. Each link is significant, but none can be perceived as a distinct unit on its own. In a chapter on Buddhist Environmental Activism from the book The Sacred Earth (Gottlieb 2003), Stephanie Kaza (2003) explains its connections with the mutual interdependence angle by means of an interesting metaphor from the Hua-Yen school of Buddhism in seventh century China featuring the cosmic jewel net of Indra that holds a multifaceted jewel placed at each of its nodes. When the jewels are clear and in place, each reflects the other and magnifies the beauty of the arrangement. However, when any of the jewels are clouded (toxic or polluted), the mirroring is disrupted. Likewise, if one of the strings on the net is tugged at, it affects all of the others and thus the overall equilibrium. Our delicate ecosystem that is bearing the brunt of our industrialized greed and overconsumption needs more than just research around climate justice or policies pertaining to carbon taxes. It needs a revolution of the human psyche which cannot be externally imposed by political, social, scientific, technological or even environmental groups but can only emerge from within oneself and be sustained through deeper self-inquiry accompanied by a radical shift in our everyday consciousness. We hope that our present paper offered our reader some sparks of inspiration and impetus for transformational change.

\section{References}

Abram, D. (1996). Spell of the sensuous. New York: Vintage Books.

Abram, D. (2010). Becoming animal: an earthly cosmology. New York: Vintage Books. https://doi.org/10. $1080 / 14688417.2010 .10589067$

Bai, H. (2001). Challenge for education: learning to value the world intrinsically. Encounter, 14(1), 4-16.

Bai, H. (2003). Learning from Zen arts: a lesson in intrinsic valuation. Journal of the Canadian Association for Curriculum Studies, 1(2), 1-14.

Bai, H., Scott, C., \& Donald, B. (2009). Contemplative pedagogy and revitalization of teacher education. Alberta Journal of Educational Research, 55, 319-334.

Barad, K. (2007). Meeting the universe halfway: quantum physics and the entanglement of matter and meaning. Duke University Press. https://doi.org/10.1515/9780822388128

Berry, T. (2006). Evening thoughts: reflecting on Earth as sacred community. San Francisco: Sierra Club.

Blenkinsop, S., \& Beeman, C. (2010). The world as co-teacher: learning to work with a peerless colleague. The Trumpeter, 26(3), 27-39.

Cavas, B., \& Cavas, P. (2020). Multiple intelligences theory-Howard Gardner. In B. Akpan and T. Kennedy (Eds.), Science education in theory and practice (pp. 405-418). New York: Springer. https://doi. org/10.1007/978-3-030-43620-9_27

Ceballos, G., Ehrlich, P. R., Barnosky, A. D., García, A., Pringle, R. M., \& Palmer, T. M. (2015). Accelerated modern human-induced species losses: entering the sixth mass extinction. Science advances. 1(5). https://doi.org/10.1126/sciadv.1400253 
Davis, J. P., \& Bellocchi, A. (2019). Intensity of emotional energy in situated cultural practices of science education. Cultural Studies of Science Education, 15, 359-388. https://doi.org/10.1007/ s11422-019-09931-0

De Sousa, A. (2012). Mind and consciousness as per. J. Krishnamurti. Mens Sana Monographs, 10(1), 198207. https://doi.org/10.4103/0973-1229.86145

Emerson, R.W. (1928). The mountain and the squirrel. Retrieved from https://www.familyfriendpoems.com/ poem/the-mountain-and-the-squirrel-by-ralph-waldo-emerson https://doi.org/10.1177/002205742810700 205

Fettes, M. (2020). Animate earth feeling itself [Personal communication].

Gendlin, E. T. (1978, 1081). Focusing. New York: Random House.

Gill, S. D. (1991). Mother earth: an American story. University of Chicago Press.

Gottlieb, R. S. (2003). This sacred earth: religion, nature, environment. London: Routledge. https://doi.org/ $10.4324 / 9780203426982$

Government of Canada. (2020) Forest Pest Management. Retrieved from https://www.nrcan.gc.ca/our-natur al-resources/forests-forestry/wildland-fires-insects-disturban/forest-pest-management/13361

Grant, G. (1969). Technology and empire. Toronto: House of Anansi.

Grass, S.J. (2014). Structures and strategies for supporting Aboriginal student success: how do instructors in Aboriginal controlled post-secondary education institutions integrate indigenous knowledge and culture into their practice? (Master's Thesis, University of British Columbia). Vancouver, British Columbia. https://open.library.ubc.ca/cIRcle/collections/ubctheses/24/items/1.0167664

Haidt, J. (2012). The righteous mind: Why good people are divided by politics and religion. New York: Vintage Books.

Hardt, M. (2015). The power to be affected. International Journal of Politics, Culture and Society, 28(3), 215-222. https://doi.org/10.1007/s10767-014-9191-x

Harrison, P. (1999). Subduing the earth: Genesis 1, early modern science and the exploitation of nature. The Journal of Religion, 79(1), 86-109. https://doi.org/10.1086/490346

Hill, D. (2008). Listening to stones-learning in Leroy Little Bear's laboratory: dialogue in the world outside. Alberta Views - The Magazine for Engaged Citizens. https://albertaviews.ca/liste ning-to-stones/

Hubbs, J. (2017). The worship of Mother Earth in Russian culture. In J. Preston (Ed.), Mother worship: theme and variations (pp. 123-144). University of North Carolina Press.

Jeong, S., Sherman, B., \& Tippins, D. (2021). The Anthropocene as we know it: posthumanism, science education and scientific literacy as a path to sustainability. Cultural Studies of Science Education. 16.

Johnston, B. (2004). Honour Earth mother. University of Nebraska Press.

Kaza, S. (2003). To save all beings: Buddhist environmental activism. In R. Gottlieb (Ed.), This sacred earth: religion, nature, environment (pp. 330-350). Routledge.

Kempf, E., \& Hillary, E. (1993). Indigenous peoples and protected areas: the law of mother Earth. London: Earthscan Publications.

Kimantas, J. (2011). The wild coast: A kayaking, hiking and recreational guide for the north and central B.C. coast. Vancouver: Whitecap Books.

Kimmerer, R. W. (2013). Braiding sweetgrass. Minneapolis: Milkweed Editions.

Lovelock, J. (2000). Gaia: A new look at life on earth. Oxford University Press.

Loy, D. (2019). Ecodharma: Buddhist teachings for the ecological crisis. New York: Simon and Schuster.

Majid, N. (2010). "My Mother was the Earth, My Father was the Sky": myth and memory in Maori novels in English. Peter Lang.

Massumi, B. (2015). Politics of affect. John Wiley and Sons.

McGilchrist, I. (2012). The master and his emissary: The divided brain and the making of the western world. London, UK: Yale University Press.

Merchant, C. (1990). The death of nature: women, ecology and the scientific revolution. Harper and Row.

Panikkar, R. (1990). A nonary of priorities. In J. Ogilvy (Ed.), Revisioning philosophy (pp. 235-246). Albany, NY: State University of New York Press.

Plumwood, V (2002) Decolonisation relationships with nature. PAN: Philosophy Activism Nature. 2; 7-30.

Rankin, A. (2009). Karmic ecology: lessons from the Jain dharma. The Trumpeter, 25(2), 1-14.

Ripple, W. J., Wolf, C., Newsome, T. M., Galetti, M., Alamgir, M., \& Crist, E. (2017). World scientists' warning to humanity: a second notice. BioScience., 67(12), 1026-1028. https://doi.org/10.1093/ biosci/bix 125

Ross, R. (1996). Returning to the teachings exploring Aboriginal justice. Penguin Canada. 
Roth, W.-M. (2021). Gardener-becoming-tree, tree-becoming-gardener: growing-together as a metaphor for thinking about learning and development. Cultural Studies of Science Education. 16.

Sharma, A. (1990). Karma and reincarnation in Advaita Vedanta. Journal of Indian Philosophy, 18(3), 219-236. https://doi.org/10.1007/BF00190312

Shiah, Y.-J. (2016). From self to nonself: the nonself theory. Frontiers in Psychology. https://doi.org/10. 3389/fpsyg.2016.00124

Snyder, G. (2010). The practice of the wild. Berkeley: Counterpoint Press.

Tu, W. (1996). Beyond the enlightenment mentality: a Confucian perspective on ethics, migration and global stewardship. The International Migration Review, 30(1), 58-75. https://doi.org/10.1177/ 019791839603000106

Whitman, W. (1933). Leaves of grass. New York: The Modern Library.

Wilber, K. (2017). The religion of tomorrow: a vision for the future of the great traditions-more inclusive, more comprehensive, more complete. Boulder, CO: Shambhala Publications.

Publisher's Note Springer Nature remains neutral with regard to jurisdictional claims in published maps and institutional affiliations.

Charles Scott is an adjunct professor in the faculty of education at Simon Fraser University. Along with Heesoon Bai, he coordinates a Master of Education program in Contemplative Inquiry and Approaches in Education. His research interests are contemplative inquiry, dialogue in education, spirituality in education, holistic education, and curriculum development, along with skiing and hiking.

Tanya Behrisch spends summers kayaking B.C.'s west coast with her family and walking barefoot on remote beaches, crisscrossing the prints of wolves, black bears, otters, weasels, mice, mink, martens, and crabs. She manages the Applied Science Co-operative Education Program at Simon Fraser University when not immersed in sea water or back-country skiing in the Coast Mountain Range. As a doctoral student, she's reading and writing about learning and living through risk. Porosity and gentleness are emerging tracks in the sand she's currently exploring.

Monica Bhattacharjee is a K-12 educator with teaching experiences in Canada, Singapore, and India. She is currently working on her $\mathrm{PhD}$ in Education at Simon Fraser University. She is passionate about cultural cognition, social justice, practical wisdom, epistemic humility, and contemplative approaches in educational philosophy and practice.

Starleigh Grass is a member of the Tsilhqot'in Nation. Starleigh is a certified K-12 teacher with experience in rural public schools in BC. She has been involved in the development and implementation of English First Peoples, a secondary language arts curriculum which uses Indigenous texts and pedagogy. Starleigh is currently in the Education Theory and Practice Program, Philosophy of Education stream, at Simon Fraser University.

Heesoon Bai is professor in the Faculty of Education at Simon Fraser University (SFU). Heesoon is an educational philosopher and a psychotherapist with deepening interest in holistic-contemplative-transformative education. She has co-edited three volumes on contemplative education (State University of New York Press). A Book Ecological Virtues: Living Well in the Anthropocene is published (2020) by University of Regina Press. Many of her academic publications can be downloaded from her SFU web depository here: http://summit.sfu.ca/collection/204 Bai's Website: http://www.sfu.ca/education/faculty-profiles/hbai.html 